№. 4245 March 10, 1951

are expected to collect and fix properly for slidemaking purposes plant materials indigenous to their respective regions or collected elsewhere by themselves. All plants, from the Algre upwards, are to be included, as are all plant structures. Each collection, upon receipt and acceptance by the Commission, will be given an exchange value of ten slides. Materials which duplicate those previously sent by others may be given a lesser exchange value, depending upon their usefulness. Members are entitled to receive in exchange any slides that they desire, up to the total of their allowances, whether these are prepared from materials sent by themselves or by others. The extensive slide collections of the California Botanical Materials Co., numbering more than six thousand individual items, will be used as a nucleus for exchange purposes. Slides will not be accepted for exchange. The Commission does not duplicate the aims or purposes of the International Depository of Cytological Slides, another member of the Union. However, one example of all cytological slides processed by the Commission will be sent to the Depository. Further information can be obtained from Dr. D. A. Johansen, International Commission for Plant Slide Exchanges, 861 East Columbia Avenue, Pomona, California.

\section{World Trade in Fertilizers}

THE attention now focused on world food production lends special interest to the thirty-fourth report published by the Commonwealth Economic Committee, "A Survey of the Trade in Fertilizers" (pp. 126 ; London: H.M. Stationery Office, 1950 ; 3s.). During 1948-49 the world usage of chemical fertilizers reached record levels, though the consumption showed signs of slackening in some areas. World production of nitrogen, potash and phosphate rose to above pre-war figures, the output being $3 \cdot 3,3 \cdot 2$ and 5 million tons, respectively. Of these, the British Commonwealth countries contributed fourteen per cent of the nitrogen and potash, and nearly twenty per cent of the phosphate. The principal source of the world's nitrogen is the atmosphere, and, though a substantial proportion is obtained as a by-product from coal, natural nitrate from Chile now provides less than ten per cent of the total. Ammonium sulphate is the chief nitrogenous fertilizer, superphosphate provides most of the phosphate, and muriate most of the potash. The United States is the world's largest consumer ; but the highest average rates of application occur in certain European countries and Japan. The British Commonwealth accounts for about ten per cent of the world consumption of nitrogen and potash and about twenty per cent of the phosphate. International trade in fertilizers, greatly reduced by the Second World War, has recovered to well above previous levels in all three plant foods. A large potential demand exists in Far Eastern countries; but its translation into effective demand depends upon the price at which supplies become available. Plans for both increased production and use are already in hand or under consideration in India, Pakistan and elsewhere. Overall supplies of nitrogen, phosphate and potash seem to be adequate, and unexploited reserves should be ample for future requirements. A world shortage of raw sulphur, however, exists, and countries contemplating increased production of superphosphate may fiad it necessery to use indigenous supplies of sulphur-bearing minerals such as pyrites, or to reduce their use of sulphuric acid.

\section{Chung Kuo Ko Hsueh or Science (China)}

THE first issue of Chung Kuo Ko Hsueh (1, No. 1 ; pp. 272; Peking: Academia Sinica; August 1950) contains seventeen papers in Chinese. It begins with an article, with an abstract in English, by L. K. Hua on the semi-homomorphism of rings ; followed by three other mathematical papers and a paper by P. C. Yin giving a new modification of Bjurström's method of graphical solution of X-ray powder photographs. K. K. Chu contributes a paper on geomagnetic elements giving main-field charts of China in Epoch 1945. C. H. Loh and his co-workers have studied the native method of extraction of sesame oil. The method depends on the replacement of oil by water in the seed after milling, and often gives a higher yield than that obtainable by expression. The distribution of vitamin $\mathrm{B}_{1}$ and nicotinic acid in rice has been investigated by Y. L. Wang and his associates, who report that more than 55 per cent of the total vitamin $B$, content is present in the scutellum, and, in the aleurone layer, 72 per cent of the total nicotinic acid. Observations on Hypoderceum conoideum (Bloch) Dietz, 1909, found in China are recorded by $\mathbf{F}$. P. Li ; and T. C. Tung contributes a paper, one of a series previously publishod (Proc. Zool. Soc.), on the ciliary action of embryonic tissues of Amblystoma punctatum and Rana palustris. Results of a field study on the effect of cotton insects on the growth and yield of cotton, with and without the use of an insecticide, are given in a paper by $H$. F. Chu and $K$. H. Chang. The journal is well printed, and is one of the three publications of the Academia, which at present consists of twenty research institutes.

\section{Survey of Thesis Literature in British Libraries}

IN extension of Col. Luxmoore Newcombe's paper on "The Accessibility of British University Thesis Literature" prepared for the sixteenth annual conference of Aslib in 1939, the Library Association has published a survey of thesis literature in British libraries (London: Library Association, 1950; $2 s$. $6 d$.; 2s. to members of the Library Association), prepared by Mr. P. D. Record, of the Bodleian Library, on the basis of a questionnaire circulated to librarians early in 1949. Mr. Record is concerned with two kinds of dissertations, the first being with those submitted to British universities for their degrees. Information received from eighteen universities indicates no uniformity of practice, either in regard to the deposition of theses in the university library, the consultation of deposited theses, or the tracing of theses, whether within the library or by lists of titles or abstracts of theses published by the university. There is no national list corresponding to the American and Continental lists, although a joint sub-committee of the Library Association and of Aslib is considering the compilation and publication of such a list. Some subjects are covered for limited periods, history having continuous lists of university research, in progress and completed, back to 1911 . The majority of theses for science degrees ultimately appear in appropriate journals; but there is no centralized source of information about work in progress, or not yet published. The second point made by Mr. Record is that he has gathered information about collections of theses from foreign universities, or not connected with universities at all, in British libraries, including the British Museum, the National Libraries of Scotland and Wales, the John Rylands Library, Manchester, and some special 